\title{
Immunologic shifts occurring during cow milk (CM) oral immunotheray (OIT)
}

\author{
Alfredo Alves Neto ${ }^{1 *}$, Conrado Martins ${ }^{1}$, Priscila Aboud Pimenta ${ }^{1}$, José Luiz De Magalhães Rios ${ }^{2}$, Fabio Kuschnir ${ }^{1,3}$, \\ Marilucia Alves Da Venda', João Bosco Magalhães Rios ${ }^{1}$
}

From 3rd WAO International Scientific Conference (WISC) 2014

Rio de Janeiro, Brazil. 6-9 December 2014

\section{Background}

The Paradigm of cow's milk allergy (CMA) management has shifted in the last years, with the introduction of the Oral Induction Tolerance (OIT) protocols to CMA. Patients with anaphylaxis have persistent and high levels of specific IgE to milk proteins, mainly casein. The purpose of this research was follow the evolution of these parameters during the different phases of CM's OIT.

\section{Methods}

Series of cases involving 15 children over 4 years and adolescents who still had anaphylaxis to cow's milk. Specific IgE levels were evaluated in three steps of OIT: at baseline, pre-treatment session (step 1); When the patient reached the concentration 1:1 (step 2); and when reaching the final volume to $150 \mathrm{ml}$ of milk a day (step 3). The differences between the levels of specific IgE were analyzed by Student's $t$ test. The adopted level of significance was $<0.05$

\section{Results}

The age mean of the sample was 8.73 years (min: 4 , Max: 19), 9 females. At step 1, the mean for specific IgE levels for milk; casein , $\alpha$-lacto albumin and B-lacto albumin were respectively : 43,96 KU/L (Min:9,0 KU/l; Max: 100,0 KU/L); 31,35 KU/L (Min:7,0 KU/1;Max: 69,3 $\mathrm{KU} / \mathrm{L}) ; 18,663 \mathrm{KU} / \mathrm{L}$ (Min:1,0 KU/1;Max: 45,5 KU/L) and 10,247 KU/L (Min:2,3 KU/1 ; Max: 29,7 KU/L). At step 3 , these values were respectively of $19,48 \mathrm{KU} / \mathrm{L}$ (Min:2,70 KU/l ;Max: 46,20 KU/L); 17,29 KU/L (Min:1,80 KU/l ; Max: 45,5 KU/L); 2,046 KU/L (Min:0,0 $\mathrm{KU} / \mathrm{l}$ and Max: 29,5 KU/L) and 4,91 KU/L (Min:1,0 KU/l; Max: $17,0 \mathrm{KU} / \mathrm{L})$. The compare of the mean of specific IgE levels between the steps 1 and 3 reached statistical

${ }^{1}$ Policlinica Geral Do Rio De Janeiro, Brazil

Full list of author information is available at the end of the article significance for all antigens: milk $(p<0,001)$; casein ( $\mathrm{p}=0,003) ; \alpha$-lacto albumin $(p=0,002)$ and B-lacto albumin $(p=0,005)$.

\section{Conclusions}

OIT to anaphylactic CMA reduces the specific IgE levels for milk proteins in parallel to developing of clinical tolerance to high volumes of milk ingestion.

\section{Authors' details}

${ }^{1}$ Policlinica Geral Do Rio De Janeiro, Brazil. ${ }^{2}$ Faculdade De Medicina De Petrópolis - Fase, Brazil. ${ }^{3}$ Rio De Janeiro State University, Brazil.

Published: 8 April 2015

doi:10.1186/1939-4551-8-S1-A196

Cite this article as: Neto et al:: Immunologic shifts occurring during cow milk (CM) oral immunotheray (OIT). World Allergy Organization Journal 2015 8(Suppl 1):A196.
Submit your next manuscript to BioMed Central and take full advantage of:

- Convenient online submission

- Thorough peer review

- No space constraints or color figure charges

- Immediate publication on acceptance

- Inclusion in PubMed, CAS, Scopus and Google Scholar

- Research which is freely available for redistribution
() Biomed Central 